\title{
SPORTA PREČU ZĪMES
}

\section{TRADEMARKS IN SPORTS}

\author{
Stella Kaprāne, Mg. iur. \\ Zvērinātu advokātu birojs “BDO Law”, juriste
}

\begin{abstract}
Summary
The aim of the current article is to define sports trademarks concept, various types of sports trademarks, their Nice classification classes, preconditions for the implementation of sports trade mark protection, as well as to bring to attention other relevant questions connected with trademark protection, such as the domain name protection. In preparation of the article, the author has studied court rulings, legal literature, various normative acts regarding trade marks and their protection. The applied methods include comparative method, analytical method, deduction and induction methods.
\end{abstract}

Atslēgvārdi: preču zīmes, sports, preču zīmju aizsardzība, sporta preču zīmju veidi, ar sporta preču zīmēm saistìti jautājumi.

Keywords: trademarks, sports, trademark protection, trademark types in sports, questions connected with sports trademarks.

\section{Sporta preču zīmju jēdziena definīcija un veidi}

Saskaṇā ar Preču zīmju likuma 1. panta astoto punktu [..] preču zìme - apzīmējums, kuru lieto, lai kādas personas preces vai pakalpojumus atšķirtu no citu personu precēm vai pakalpojumiem. ${ }^{1}$ Sporta preces ir sporta apgērbs, apavi, galvassegas, sporta inventārs, suvenīri, uztura bagātinātāji u. c., savukārt sporta pakalpojumi ir sporta klubu, spēlētāju u. c. sniegtie pakalpojumi. Sporta preču zīmi var definēt kā apzīmējumu, kuru lieto, lai kādas personas sporta preces vai sporta pakalpojumus atšķirtu no citu personu precēm vai pakalpojumiem.

Atbilstoši Preču zīmju likuma 4. panta otrajai daḷai kā sporta preču zīmes pēc registrējamo apzīmējumu veidiem var reǵistrēt:

1. Vārda preču zīmes (piemēram, sporta klubu vai komandu saukḷi, klubu nosaukumi, spēlētāju iesaukas u. c.).

2. Figurālas preču zīmes (sporta klubu, sporta apgeērba ražotāju logotipi u. c.).

3. Telpiskas preču zīmes (sporta apavu vai inventāra īpaša forma - nošķirt no patentējamiem objektiem u. c.).

4. Novietojuma preču zìmes (svìtras uz Adidas apaviem u. c.).

5. Ornamenta preču zīmes (sporta preču, inventāra raksti, apdrukas).

6. Krāsu preču zīmes u. c. (sporta klubu krāsu lietojums noteiktā veidā un salikumā).

\footnotetext{
1 Preču zīmju likums: LV likums. Pieņemts 06.02.2020. [06.02.2020. red.].
} 
Visplašāk izmantotās sporta preču zīmes ir apzīmējumi, kas izmantojami uz sporta apgérba, apaviem, inventāra, sporta auto (Adidas, Nike, Reebok logo, Ferrari Testarossa u. c.) - gan figurālās preču zīmes, gan noteikti ornamenti (līnijas, raksti u. c.). Plaši tiek lietotas arī telpiskas preču zìmes (apavu, sporta inventāra forma, to faktūra u. c.), sporta klubu, komandu, spēlētāju, sporta preču ražotāju, pakalpojumu sniedzēju, kā arī uztura bagātinātāju un pārtikas produktu apzīmējumi un saukḷi (kā vārdiskās preču zīmes) sportiskam dzīvesveidam.

Kā ārvalstu preču zīmju piemērus var minēt sporta dzēriena Gatorade preču zīmi, kas reǵistrēta Amerikas Savienotajās Valstīs; sportista skrējēja Useina Bolta (Usain Bolt) To Di World saukḷa un Lightning Bolt pozas silueta vārda un figurālo preču zīmi; basketbolista Džeimsa Lebrona (James LeBron) Beast Mode preču zīmi un "Mērḳē augstu un tiecies uz zvaigznēm" (angḷu val. - Aim High and Shoot for the Stars) saukli; Sanfrancisko beisbolista Kolina Kapernika (Colin Kaepernick) tā dēvēto Kaepernicking pozas ("bicepsa skūpsts") preču zīmi; Denveras komandas (Denver Broncos) amerikāṇu futbola spēlētāja (Tim Tebow) lūgšanu pozas spēles laikā (Tebowing) preču zīmi u. tml.

Sporta preču zīmes praksē parasti tiek registrētas Nicas klasifikācijas (Nicas Nolīgums par preču un pakalpojumu starptautisko klasifikāciju preču zīmju reǵistrācijas vajadzībām) klasēs (atkarībā no plānotā izmantojuma): 9. klasē - aizsargḳiveres, aizsargbrilles un zobu aizsargi sportam; 25. klasē - apgèrbi, apavi, galvassegas; 28 . klasē - vingrošanas un sporta preces; 32 . klasē - enerğijas dzērieni, izotoniskie dzērieni, ar proteīniem bagātināti sporta dzērieni u. c. Sporta preču zīmju jomā tiek reǵistrētas gan Eiropas Savienības, gan dalībvalstu preču zīmes, gan arī ASV preču zīmes (ASV ir l̦oti aktuāla spēlētāju saukḷu, iesauku aizsargāšana ar preču zīmju palīdzību).

Reǵistrācijas priekšnosacījums kā jebkurai preču zīmei, saskaṇā ar Preču zīmju likuma 4. panta pirmo daļu, ir apzīmējuma atšķirtspēja; preču zīmju reǵistrā apzīmējumam jābūt atveidotam tā, lai var skaidri un nepārprotami noteikt, kas ir preču zīmes īpašniekam piešḳirtās aizsardzības priekšmets. Ja reǵistrētas preču zìmes netiek lietotas 5 gadus, tad, lai nezaudētu tiesības uz tām, šo zīmju īpašniekiem, tostarp arī sporta preču jomā, aktuāls un nozīmīgs ir arī preču zīmju faktiskās izmantošanas jautājums.

Atbilstoši Preču zīmju likuma 26. pantam, 43. panta piektajai dal̦ai, 61. panta piektajai daḷai un 63. pantam preču zīmes reǵistrāciju var atcelt, ja preču zīme secīgu piecu gadu laikposmā pēc tās reǵistrācijas procedūras pabeigšanas nav faktiski izmantota saistībā ar precēm un pakalpojumiem, kuriem tā reǵistrēta, vai ja šāda izmantošana tikusi pārtraukta vismaz uz secīgu piecu gadu laikposmu, pirms iesniegts prasības pieteikums par preču zīmes reǵistrācijas atcelšanu, un šai neizmantošanai nav pienācīga attaisnojuma. Analog̣isks regulējums attiecībā uz Eiropas Savienības preču zìmi paredzēts arī Eiropas Parlamenta un Padomes Regulā (ES) 2017/1001 (2017. gada 14. jūnijs) par Eiropas Savienības preču zīmi. ${ }^{2}$

Sporta preču zīmju aizsardzībai ieteicams reǵistrēt preču zìmi attiecīgajā Nicas klasifikācijas klasē, izvēlēties starp Eiropas Savienības un dalībvalstu preču zīmēm, kā arī izmantot preču zīmes īpašnieka tiesības aizliegt citiem preču zīmes vai tai sajaucami līdzīga apzīmējuma izmantošanu. Papildus pastāv pienākumrīkojuma pieprasīšanas iespēja, lai aizliegtu izplatīt preces, sniegt pakalpojumus, ar kuriem aizskartas preču zīmju īpašnieka tiesības.

\footnotetext{
2 Regula (ES) 2017/1001 par Eiropas Savienības preču zīmi. Pieņemta 14.06.2017. [13.02.2018. red.].
} 


\section{Sporta preču zīmes Eiropas Savienības Tiesas praksē}

Eiropas Savienības Tiesa (turpmāk - EST) sporta preču zīmju jautājumus skatījusi vairākās lietās. Piemēram, EST 2015. gada 10. decembra spriedumā lietā Nr. T 615/14 Fútbol Club Barcelona pret Iekšējā tirgus saskaņošanas biroju (OHIM) pamatlietā 2013. gada 24. aprīlī prasitāja Fútbol Club Barcelona bija iesniegusi Iekšejjā tirgus saskaņošanas birojam (preču zīmes, paraugi un modelii) (OHIM) reg̣istrācijas pieteikumu Eiropas Savienības grafiskās preču zīmes - futbola kluba vairoga - reg̣istrācijai attiecībā uz Nicas klasifikācijas 16., 25. un 41. klašu precēm un pakalpojumiem (papīrs, kartons, izstrādājumi no šiem materiāliem u. c.; apgèerbs, apavi, galvassegas; izglîtîba; apmācība; izklaide; sporta un kultūras pasākumi). ${ }^{3}$

Pieteikums par visiem pieprasìtajiem produktiem un pakalpojumiem minētajā lietā tika noraidīts. Pretendents pārsūdzēja lēmumu. Apelācijas pirmā padome apelāciju noraidīja, jo reğistrācijai pieteiktajai preču zīmei neesot raksturīgas atšķirtspējas un tai nav neviena îpaša elementa, kas varētu nekavējoties piesaistìt patērētāja uzmanību kā norādi uz dažādu preču un pakalpojumu komerciālo izcelsmi, ņemot vērā, ka futbola klubu (kā arī dažādu citu sporta klubu) logotipos vairoga formas apzīmējuma lietojums ir plaši izplatīts un ka konkrētajā reǵistrācijai pieteiktajā apzīmējumā nav nekādu unikālu, atšķirtspēju nodrošinošu elementu, kas varētu piesaistīt patērētāja uzmanību kā norādi uz dažādu preču un pakalpojumu komerciālo izcelsmi un to nošķirt no pārējiem apzīmējumiem. ${ }^{4}$

Tādējādi secināms, ka sporta klubu logotipos ietvertās dažādās formas, tostarp vairoga forma, pašas par sevi nevar nodrošināt pietiekamu atšķirtspēju un arī sporta preču zīmēm jānodrošina pietiekama apzīmējumu atškirirspēja attiecīgajā jomā, kurā tās tiks izmantotas un plānots reg̣istrēt.

Savukārt EST 2020. gada 22. oktobra spriedumā apvienotajās lietās Nr. C720/18 un C721/18 Ferrari SpA pret DU (Ferrari Testarossa lieta) skatìts attiecībā uz sporta automašīnām (un to rezerves daḷām) reǵistrētās preču zīmes aizsardzības jautājums. Pamatlietā 1987. gada 22. jūlijā preču zīme Testarossa tika reǵistrēta Pasaules intelektuālā īpašuma organizācijā kā starptautiska preču zīme attiecỉbā uz Nicas klasifikācijas 12. klasē ietilpstošām precēm, vēlāk - arī Vācijā. Diseldorfas apgabaltiesa lēma par to izslēgšanu no registra atcelšanas dẹl, pamatojoties uz to, ka nepārtrauktā piecu gadu laikposmā Ferrari šìs preču zīmes nav faktiski izmantojusi Vācijā un Šveicē precēm, attiecībā uz kurām tās ir reǵistrētas. Augstākā tiesa Diseldorfā nolēma apturēt tiesvedību un uzdot prejudiciālus jautājumus - vai attiecībā uz preču zīmes izmantošanu jāṇem vērā tās izmantošana ìpašam tirgus segmentam. ${ }^{5}$

Ferrari Testarossa lietā no EST atzina, ka preču zīmi tās īpašnieks faktiski izmanto, ja tas sniedz noteiktus pakalpojumus saistībā ar precēm, kas agrāk ir pārdotas ar šo preču zīmi, ar nosacỉjumu, ka šie pakalpojumi tiek sniegti ar minēto preču zīmi un ka preču zīme, kas reǵistrēta attiecībā uz preču un to veidojošo sporta auto rezerves daḷu kategoriju, ir jāuzskata par tādu, kas ir faktiski izmantota attiecỉbā uz visām šajā kategorijā ietilpstošajām precēm un to rezerves daḷām arī

\footnotetext{
${ }^{3}$ EST 10.12.2015. spriedums lietā Nr. T 615/14 Fútbol Club Barcelona pret Iekšējā tirgus saskan̨ošanas biroju (OHIM).

4 Turpat.

${ }^{5}$ EST 22.10.2020. spriedums apvienotajās lietās Nr. C720/18 un C721/18 Ferrari SpA pret DU.
} 
tad, ja tā lietota vienīgi saistībā ar dažu minēto preču rezerves daḷām un piederumiem. Izņēmums - ja vien no atbilstošajiem faktiem un pierādījumiem neizriet, ka patērētājs, kurš vēlas iegādāties šìs pašas preces, tās uztvers kā tādas, kas ir preču kategorijas, saistībā ar kurām attiecīgā preču zīme ir registrēta, autonoma apakškategorija. ${ }^{6}$

Līdzīgi ticis lemts arī agrāk pieņemtā EST spiedumā attiecībā uz Nicas klasifikācijas 25. klases precēm reǵistrētām preču zìmēm - EST 2020. gada 16. jūlija spriedumā lietā Nr. C-714/18 P ACTC GmbH v. Eiropas Savienības Intelektuālā īpašuma birojs. Minētajā lietā EST secina, ka nav mākslīgi jānošķir papildu preču vai pakalpojumu, attiecībā uz kurām registrēta un izmantota preču zīme, aizsardzības apakškategorijas, mākslīgi samazinot preču zīmes sniegtās aizsardzības apmēru. Kaut gan nosakot, cik plašs ir attiecīgās preču zīmes aizsardzības apmērs, ir jāṇem vērā preču vai pakalpojumu izmantošanas mērķi un funkcionālie uzdevumi, tomēr preču zìmes aizsardzība un preces vai pakalpojumi, attiecībā uz kuriem reǵistrēta preču zīme, kā arī notikusi tās faktiskā izmantošana, ir tulkojami un aplūkojami plaši, nesašaurinot preču zīmes īpašniekam piešķirto preču zīmes aizsardzības apmēru. ${ }^{7}$

Tādējādi, nosakot attiecīgās preču zīmes aizsardzības apmēru, ir jāṇem vērā preču vai pakalpojumu izmantošanas mērḳi un funkcionālie uzdevumi, tomēr vienlaikus šaubu gadījumā preču zīmes aizsardzība skatāma plaši, t. i., mākslīgi nenodalot preču vai pakalpojumu apakškategorijas, attiecībā uz kurām preču zīme tiek registrēta, un nesašaurinot preču zīmes ìpašniekam piešķirto attiecīgās preču zìmes aizsardzību.

Savukārt EST 2002. gada 12. novembra spriedumā lietā Nr. C206/01 Arsenal Football Club plc. v. Matthew Reed aplūkota preču zīmes aizsardzība saistībā ar sporta fanu lojalitātes savam sporta klubam izrādī̌sanu. Arsenal FC ir slavens futbola klubs, kas spēlē Anglijas pirmajā līgā. Strīds pamatlietā bija starp Arsenal Football Club plc. un preču tirgotāju par šal̦lu (ar Arsenal uzrakstu) tirdzniecību. Rīda (Reed) kungs vairākos kioskos, kas atradās pie Arsenal FC stadiona žoga, pārdeva futbola suvenīrus un citas preces, uz kurām gandrīz vienmēr ir apzīmējumi, kas norāda uz Arsenal FC sporta klubu, lai arī tikai daḷa no viņa tirgotajām precēm bija iegādātas no Arsenal FC sporta kluba. Minēto uzrakstu kā preču zīmi uz apgēēbu un aksesuāru izstrādājumiem bija reǵistrējis Arsenal FC attiecībā uz vārdiem Arsenal un Arsenal Gunners. Turklāt Arsenal FC sporta klubs arī pats izplatīja ar Arsenal FC preču zīmi apzīmētās preces, izmantojot savu izplatītāju tīklu. Anglijas tiesa tiesvedībā pret tirgotāju par neoficiālo preču tirdzniecību nolēma apturēt tiesvedỉbu un uzdot EST prejudiciālus jautājumus, tostarp, vai trešā persona var atsaukties uz preču zìmes lietojumu kā atbalsta, lojalitātes vai piederības apliecinājumu preču zīmes īpašniekam. ${ }^{8}$

EST lietā secina, ka šādā gadījumā konstatējams preču zīmju īpašnieka tiesību pārkāpums, konstatējot, ka nav nekādas atšķirības, vai citai personai piederoša preču zīme bez tā ìpašnieka atḷaujas tiek izmantota precēm un izplatīta tikai tīri komerciālā nolūkā vai tirgota, nodrošinot sporta kluba fanu iespējas publiski paust savu lojalitāti pret sporta klubu, kas apzīmēts ar preču zīmi. ${ }^{9}$ Sporta preču zīmju

${ }^{6}$ EST 22.10.2020. spriedums apvienotajās lietās Nr. C720/18 un C721/18 Ferrari SpA pret DU.

${ }^{7}$ EST 16.07.2020. spriedums lietā Nr. C-714/18 P ACTC GmbH v. Eiropas Savienības Intelektuālā īpašuma birojs.

${ }^{8}$ EST 12.11.2002. spriedums lietā Nr. C206/01 Arsenal Football Club plc. v. Matthew Reed.

9 Turpat. 
lietošanas pārkāpuma konstatēšanai jānosaka preces, pakalpojumi, attiecībā uz kuriem preču zīmes reg̣istrētas un tiek izmantotas, kā arī tā sabiedrības dạ̦a, kas potenciāli varētu būt konkrētās preces vai pakalpojuma mērķauditorija, un, ņemot vērā minēto, jāanalizē apzīmējumu savstarpējā līdzība un sajaukšanas iespēja attiecīgās sabiedrības daḷas izpratnē. Neaț̣autas preču zīmes izmantošanas gadỉjumā nav nozīmes tam, vai apzīmējums ir izmantots, lai izrādītu lojalitāti un cieņu pret attiecīgās preču zīmes īpašnieku - sporta klubu, sportistu vai sporta apgēerbu zīmola îpašnieku - un atbalstîtu to.

EST 2015. gada 21. maija spriedumā lietā Nr. T 145/14 Adidas AG pret Iekšèjāa tirgus saskaņošanas biroju tika skatīts apzīmējuma sajaucamās līdzības jautājums. 2009. gada 1. jūlijā persona, kas iestājusies lietā, Shoe Branding Europe BVBA Iekšèjā tirgus saskaṇošanas birojā iesniedza Eiropas Savienības preču zīmes reǵistrācijas pieteikumu attiecībā uz Nicas līguma 25. klases precēm, apaviem. Reǵistrācijas pieteikumā zīme ir aprakstìta kā pozīcijas zīme, kas sastāv no divām paralēlām līnijām, kuras izvietotas uz apavu augšējās daļas ārējās virsmas. Paralēlās līnijas apzīmējumā stiepās no apavu vienīgās malas un slīpi atpakaḷ uz apavu iekšpusi, un ar punktētu līniju bija apzīmēta preču zīmes atrašanās vieta, tomēr minētā līnija, pēc reǵistrācijas pieteicēja uzskata, neesot preču zīmes sastāvdal̦a. ${ }^{10}$

Pamatlietā prasītāja Adidas $A G$ iesniedza iebildumus pret apzīmējuma kā preču zīmes reg̣istrāciju, atsaucoties uz agrākajām Adidas īpašumā esošajām Eiropas Savienības un Vācijas preču zīmēm - grafiskām preču zīmēm, kas reǵistrētas apaviem un sporta un ikdienas apaviem, uz Nicas klasifikācijas 25. klases precēm, kā arī grafisku preču zīmi, kas reǵistrēta attiecībā uz Austriju, Bulgāriju, Beniluksa valstīm, Čehijas Republiku, Vāciju, Franciju, Ungāriju, Itāliju, Portugāli, Rumāniju, Slovēniju un Slovākiju, uz Nicas klasifikācijas 25. klases precēm. Minētie iebildumi tika noraidīti, par Iebildumu nodal̦as lēmumu iesniegta apelācijas sūdzība, tomēr arī tā tikusi noraidīta. ${ }^{11}$

EST spriedumā secina, ka apzīmējumu sajaukšanas iespēja ir jānovērtē globāli, ņemot vērā, kā attiecīgā sabiedrība uztver šos apzīmējumus un preces vai pakalpojumus, un visus faktorus, kas attiecas uz lietas apstākḷiem. Iekšējā tirgus saskaņošanas biroja Apelācijas padome uzskatija, ka svìtru novietojums un skaits ir l̦oti nozìmīgi, jo svìtras uz apaviem ir l̦oti plaši izplatīi elementi, tādēl apzīmējumu atšķirības svìtru novietojumā un skaitā netiktu nepamanītas, vienlaikus secinot, ka šajā jomā patēēêājs nav apveltìts ar lielu uzmanību pret preču zīmēm un to savstarpējo atšķirtspēju. Tomēr, saskaṇā ar EST viedokli, šāds secinājums nonāk pretrunā ar faktu, ka šo preču patērētājs neuzrāda lielu uzmanību un secina, ka pārkāptas agrāko reǵistrēto preču zīmju īpašnieku tiesības un ka apstrīdētais lēmums jāatceḷ. ${ }^{12}$

Tātad secināms, ka sporta jomā sajaukšanas iespēja ir jānovērtē globāli, ņemot vērā attiecīgās sabiedrības uztveri, un ka preču pircēji un pakalpojumu lietotāji ir apveltîti ar pietiekami lielu uzmanību un zināšanām, lai spētu atšşiirt dažǎdu ražotāju preču zīmes un apzīmējumus, kas satur līdzīgus elementus, piemēram, svītras. Vienlaikus jāizvērtē arī preču zīmes atšķirtspēja kopsakarā ar attiecīgo jomu un sporta veidu, kurā tā tiek izmantota, jo var būt atškirīibas gan preču un

\footnotetext{
${ }^{10}$ EST 21.05.2015. spriedums lietā Nr. T145/14 Adidas AG pret Iekšējā tirgus saskanošanas biroju (OHIM).

11 Turpat.

12 Turpat.
} 
pakalpojumu mērķauditorijā, gan to spējā izvērtēt apzīmējumu atšķirtspēju, kā arī tajā izmantotajās preču zīmēs un preču un pakalpojumu veidos. ${ }^{13}$

EST 2018. gada 26. aprīḷa spriedumā lietā Nr. T 554/14 Lionel Andrés Messi Cuccittini pret Eiropas Savienības Intelektuālā ìpašuma biroju analizējusi preču zīmes atpazīstamību kopsakarā ar tās pieteicēja kā slavena sportista publicitāti. Futbolists Mesi (Lionel Andrés Messi Cuccittini) bija iesniedzis pieteikumu par Eiropas Savienības preču zīmes reǵistrāciju. Preces, kurām ir pieprasīta reǵistrācija, ietilpa Nicas klasifikācijas 9. klasē (avārijas (glābšanas) aparāti un instrumenti), 25. klasē (apgērbi, apavi, galvassegas) un 28. klasē (vingrošanas un sporta piederumi, kas nav ieklauti citās klasēs). ${ }^{14}$

Džeimss Mansferers Koma (Jaime Masferrer Coma) izteica iebildumus, norādot uz agrākajām tiesībām uz registrētām preču zīmēm Massi, kas registrētas, tostarp uz Nicas 9., 25. un 28. klases precēm un pakalpojumiem. Reǵistrācija tika noraidīta, arī Eiropas Savienības Intelektuālā īpašuma biroja pirmā apelācijas padome apelācijas sūdzību noraidīja. Pieteicējs vērsās tiesā, tomēr, pēc Apelācijas padomes domām, nekas no lietas materiāliem neliecinot, ka preču zīmi visi attiecīgie patērētāji konceptuāli saistīs ar futbolistu Mesi. EST, izskatot lietu, secina: ir nepareizi uzskatīt, ka Laionels Mesi (Lionel Messi) slavens tikai tajā sabiedrības daḷā, kuru interesē futbols un sports kopumā, un ka saprātīgi uzmanīgs un labi informèts preču patērētājs grafisko apzīmējumu Massi uztvers kā slavenā futbola spēlētāja preču zìmi, nevis kā vienu no daudziem itāḷu zīmoliem. ${ }^{15}$

Tādējādi secināms, ka sportistu slavas un reputācijas dēḷ vidusmēra patērētājs, saskaroties ar apzīmējumu, kas satur sportista vārdu, to saistīs ar attiecīgo sportistu un preču zīmi uzskatīs par tam piederošu.

\section{Ar sporta preču zìmēm saistīti jautājumi}

Kā viens no jautājumiem, kas saistīts ar sporta preču zīmēm, minams "40. noteikums" - pretrunīgi vērtēts Olimpiskās hartas noteikums, kas neḷauj sportistiem, kuri piedalās spēlēs, izmantot savu vārdu, tēlu vai sporta sniegumu reklāmā tā dēvētajā tumšajā periodā (laikā tieši pirms olimpiskajām sporta spēlēm un šo spēlu laikā) bez Starptautiskās Olimpiskās komitejas (turpmāk - SOK) atḷaujas. ${ }^{16}$ Apvienotajā Karalistē 1995. gada Olimpiskā simbola (Aizsardzības) likums (Olympic Symbol (Protection) Act, OSPA) arī nodrošina īpašu aizsardzību dažādiem ar olimpiskajām spēlēm saistītiem vārdiem, kā arī olimpiskiem simboliem un devīzei. ${ }^{17}$ Saskaṇā ar minēto regulējumu personām, kas nav saṇēmušas speciālas SOK at l̦aujas, ir ierobežotas iespējas izmantot olimpisko spēḷ simboliku un sportistiem, kas šajās spēelēs piedalās, piederošās preču zīmes.

${ }^{13}$ WIPO Intellectual Property Handbook: Policy, Law and Use. $2^{\text {nd }}$ ed. WIPO: Geneva, 2004.

14 EST 26.04.2018. spriedums lietā Nr. T 554/14 Lionel Andrés Messi Cuccittini pret Eiropas Savienības Intelektuālā ìpašuma biroju.

15 Turpat.

16 Starptautiskā olimpiskā komiteja. Rule 40 Materials. 2021. Pieejams: https://www.olympic.org/athlete365/ rule-40 [aplūkots 14.03.2021.]; Law in Sports. Navigating Olympic Advertising: Rule 40 - A Global Perspective. 2021. Pieejams: https:/www.lawinsport.com/topics/features/item/navigating-olympic-advertising-rule-40-a-global-perspective\#: :text=\%E2\%80\%9CRule $\% 2040 \% E 2 \% 80 \% 9 D \% 20$ is\%20the\%20 somewhat,the\%20permission\%20 of\%20the\%20IOC [aplūkots 14.03.2021.].

17 Olimpisko simbolu aizsardzības likums (Olympic Symbol (Protection) Act): Apvienotās Karalistes likums. 1995. 
2012. gadā sportisti sāka protestēt, apgalvojot, ka šādi noteikumi ir pārāk ierobežojoši un negodīgi, nel̦auj sportistu ilgtermiņa sponsoriem izmantot to atpazīstamību reklāmās un mārketingā, tādējādi ierobežojot pašu sportistu spēju gūt ienākumus. Šobrīd minētajās sporta spēlēs atḷauts izmantot atškiirīgu pieeju katrai valstij, atḷautas reklāmas, kurās piedalās sportisti ar nosacỉjumu, ka reklāmas par olimpisko spēḷu tēmu joprojām ir aizliegtas (izṇemot attiecībā uz pašu olimpisko sporta spēḷu organizētājiem), kuras veicina pašu spēḷu atpazīstamību.

Sporta preču zīmju aizsardzības jomā aktuāls ir arī ambush jeb slēptais mārketings. Daži uzṇēmumi, kas nav olimpisko sporta spēlu, noteiktu sporta klubu, spēlētāju un preču zīmju īpašnieku oficiāli partneri, cenšas bez maksas tikt saistīti ar to atpazīstamību. Tas ir negodīgi pret uzņēmumiem, kas finansiāli atbalsta spēlētājus, sporta klubus un spēlu turnīrus, pret sporta klubiem, sportistiem, kā arī pret sporta preču un pakalpojumu preču zīmju īpašniekiem, jo sportā mārketinga izdevumi ir ievērojami un spēlētāju profesionālās spējas ir tikai viens no elementiem, kas ietekmē preču zīmes atpazīstamību, kā arī komerciālos panākumus. ${ }^{18}$

Slēptā mārketinga problēma un pastāvošais intelektuālā īpašuma (tostarp preču zīmju aizsardzības) regulējums valstīm liek pieņemt īpašus valsts tiesību aktus, lai novērstu slēpto mārketingu. Tomēr, tā kā šie likumi ir spēkā tikai noteiktās teritorijās, savukārt sporta spēles tiek organizētas visā pasaulē, ir svarīgi izmantot arī parastos juridiskos līdzekḷus, piemēram, preču zīmju reǵistrāciju un preču zīmju sniegtos aizsardzības līdzekḷus, kā arī negodīgas konkurences aizlieguma regulējumu. ${ }^{19}$

Arī strīdi par domēnu nosaukumiem ir l̦oti aktuāls jautājums, kas var skart arī preču zīmju lietošanas jautājumu. Piemēram, domēnu nosaukumu strīdā lietā Justdoit.net Nike, Inc. pret Circle Group Internet, Inc. tika izvērtēta domēna nosaukuma reg̣istrācijas labticība situācijā, kad agrāk pastāvēja reg̣istrētas preču zīmes, kas pieder citai personai. Lietā domēna nosaukums justdoit.net bija reǵgistrēts Network Solutions, Inc. Herndonā, Virdžīnijā, Amerikas Savienotajās Valstīs. 2002. gadā Pasaules intelektuālā īpašuma organizācijas arbitrāžas un starpniecības centrs sañēma sūdzību. ${ }^{20}$

Daudzu gadu garumā sūdzības iesniedzējs bija izmantojis un veicinājis savu preču zīmju atpazīstamību visā pasaulē saistībā ar apaviem, apgèrbu, sporta aprīkojumu, mazumtirdzniecības veikalu pakalpojumiem, tīmekḷa saziṇu, informācijas pakalpojumiem un citām saistītām precēm un pakalpojumiem. Sūdzības iesniedzējs apgalvo, ka viṇa preču zīmes ir plaši atpazīstamas Amerikas Savienotajās Valstīs, Austrālijā, Kanādā un Eiropas Savienībā. ${ }^{21}$

Minētajā lietā tika secināts, ka l̦aunprātīgu nodomu reǵistrācijas laikā parasti var konstatēt tikai ar pierādījumu palīdzību, jo atbildētājs reti atzīs nodomu launprātīgi izmantot citai personai piederošas reǵistrētas preču zīmes kā domēnu no-

18 Starptautiskā olimpiskā komiteja. Rule 40 Materials. 2021. Pieejams: https://www.olympic.org/athlete365/ rule-40 [aplūkots 14.03.2021.]; Law in Sports. Navigating Olympic Advertising: Rule 40 - A Global Perspective. 2021. Pieejams: https://www.lawinsport.com/topics/features/item/navigating-olympic-advertising-rule-40-a-global-perspective\#: :text=\%E2\%80\%9CRule\%2040\%E2\%80\%9D\%20is\%20the $\% 20$ somewhat,the\%20permission\%20of\%20the\%20IOC [aplūkots 14.03.2021.].

19 Wipo Magazine. Protecting the Olympic Properties. 08.2016. Pieejams: https://www.wipo.int/wipo_magazine/en/2016/04/article_0004.html [aplūkots 14.03.2021.].

${ }^{20}$ WIPO Arbitrācijas un mediācijas centrs. Nike, Inc. v. Circle Group Internet, Inc. Lieta Nr. D2002-0544. 10.09.2002. Pieejams: https:/www.wipo.int/amc/en/domains/decisions/html/2002/d2002-0544.html [aplūkots 14.03.2021.].

21 Turpat. 
saukumus. Minētajā lietā pietiek ar to, ka šeit tiek nolemts, ka sūdzības iesniedzējs regístrācijas laikā nav pierādījis respondenta mala fides jeb l̦aunprātīgu nodomu. ${ }^{22}$

\section{Kopsavilkums}

1. Sporta preču zīme ir apzīmējums, kuru lieto, lai kādas personas sporta preces vai sporta pakalpojumus atšķirtu no citu personu precēm vai pakalpojumiem.

2. Sporta preču zīmes var iedalìt atkarībā no produkta vai pakalpojuma, kuram tās tiek izmantotas (apgēerbs, apavi un aksesuāri; sporta aprīkojums; sporta pārtikas preces un uztura bagātinātāji; sporta klubu un spēlētāju logotipi; sporta pakalpojumi), un reǵistrēt tās uz attiecīgās Nicas klasifikācijas precēm un pakalpojumiem.

3. Sporta preču zīmes var reǵistrēt kā vārdiskas preču zīmes, grafiskas preču zīmes, trīsdimensiju preču zìmes, pozīcijas zīmes, figurālas preču zīmes u. tml. Sportistu slavas un reputācijas dēḷ vidusmēra patērētājs, saskaroties ar apzīmējumu, kas satur sportista vārdu, to saistīs ar attiecīgo sportistu un preču zìmi uzskatīs par viņam piederošu.

4. Konstatējot preču zīmes pārkāpuma faktu, jāṇem vērā attiecīgās preču zìmes, tās īpašnieka (piemēram, sportista, sporta kluba) reputācija. Sporta klubu logotipos ietvertās dažādas formas, tostarp vairoga formas, preču zīmes pašas par sevi nevar nodrošināt pietiekamu atšķirtspēju, un arī izmantojamajām sporta preču zīmēm jānodrošina pietiekama apzīmējumu atšksirtspēja attiecīgajā jomā, kurā tās tiks izmantotas un plānots registrēt.

5. Trešajām personām bez sporta preču zīmes ìpašnieka atḷaujas nav tiesību izmantot preču zìmi arī tad, ja kā iegansts tiek minēts lojalitātes paušana attiecīgajam spēlētājam, sporta klubam.

6. Papildus preču zīmēm sportā aktuāli ir arī jautājumi, kas saistīti ar sporta preču zīmēm, - domēnu nosaukumi, dažādu sacensību, sporta klubu u. c. noteiktie nekonkurēšanas ierobežojumi un ierobežojumi spēlētājiem izmantot reklāmu un reklamēt tiem piederošās preču zīmes pirms noteiktām spēlēm. Tas var ietekmēt preču zīmju reǵistrāciju un aizsardzību, kā arì izmantošanu.

22 WIPO Arbitrācijas un mediācijas centrs. Nike, Inc. v. Circle Group Internet, Inc. Lieta Nr. D2002-0544. 10.09.2002. Pieejams: https://www.wipo.int/amc/en/domains/decisions/html/2002/d2002-0544.html [aplūkots 14.03.2021.]. 